๑ Entomologica Fennica. 10 June 1999

\title{
Revision of the genus Psoricoptera Stainton, 1854 (Lepidoptera, Gelechiidae), with the description of two new Asian species
}

\author{
Kyu-Tek Park \& Ole Karsholt
}

Park, K-T. \& Karsholt, O. 1999: Revision of the genus Psoricoptera Stainton, 1854 (Lepidoptera, Gelechiidae), with the description of two new Asian species. — Entomol. Fennica 10: 35-49.

The Palaearctic gelechiid genus Psoricoptera Stainton, 1854 is revised. Two previously described species, gibbosella (Zeller) and speciosella Teich are recognized based on differences in genitalia; both have a trans-Palaearctic distribution. Their distinction is supported by differences in the morphology and biology of the early stages. Chelaria triorthias (Meyrick) and Lita lepigreella Lucas are placed in synonymy with gibbosella (syn. n.). Two new species $P$. latignathosa sp. n. $P$. kawabei sp. n. are described from E. Asia. Infraspecific variation in the genitalia of Psoricoptera is discussed.

Kyu-Tek Park, Center for Insect Systematics, Kangwon National University, Chuncheon, 200-701 Korea.E-mail: cispa@cc.kangwon.ac.kr

Ole Karsholt, Zoological Museum, Universitetsparken 15, DK-2100, Kфbenhavn $\emptyset$, Danmark. Email: okarsholt@zmuc.ku.dk

Received 12 July 1997, accepted 11 February 1998

\section{Introduction}

The genus Psoricoptera was erected by Stainton (1854) for a single aberrant gelechiid moth, $G e$ lechia gibbosella Zeller, 1839, which he placed between the genera Depressaria and Gelechia. Psoricoptera exibits in most taxonomically important characters a remarkable variability, which is quite unusual in gelechiids. Up till now it was unsetteled if the hitherto described taxa of Psoricoptera represented one or more species.

Meyrick (1925) synonymized Psoricoptera with Chelaria Haworth, 1828, an objective junior synonym of Hypatima Hübner, 1825 (Chelariini), but most authors continued to use Psoricoptera for gibbosella, and it was listed as a valid genus by Sattler (1973). Psoricoptera shares with Hypatima the rough scales beneath second segment of labial palpus, but we do agree with
Pitkin's (1984: 6) placement of it in the Gelechiini. Karsholt \& Riedl (1996) placed Psoricoptera between Gelechia Hübner, 1825 and Mirificarma Gozmány, 1955.

Up to date three species: gibbosella (Zeller), speciosella Teich and triorthias (Meyrick), all Palaearctic, have been assigned to Psoricoptera. Lita lepigreela Lucas, described from Algeria, is here considered a synonym of gibbosella.

For about 20 years, Scandinavian microlepidopterists had recognized that another species of Psoricoptera may occur in North Europe besides gibbosella, and that the name $P$. speciosella Teich, 1893 was available for the former. This was first pointed out by Harry Krogerus (pers. comm.) and later published by Svensson (1982). The picture became less clear when material from other geographical areas was studied (Karsholt 1995). Svensson (1982) found a difference in the number of 
microspines on the aedeagus between Swedish specimens attributed to speciosella and gibbosella (10-15 and 21-43 spines, respectively). We examined this character in specimens from different parts of Europe and counted 7-13 spines in specimens with a speciosella type of uncus and 21-43 spines in specimens with a gibbosella type of uncus. However, these spines are not easily discernable due to their small size, and their number may be counted differently according to the position of the preparation. No helpful studies on the female genitalia of Psoricoptera have been published.

Recently, the assumption of the existence of two species of Psoricoptera in Europe was strongly supported by evident differences in biology and in colour of larvae (Kaitila 1996). Within the Gelechiidae it is unusual to find noticeable infraspecific variation in the shape of genitalia. In Psoricoptera, morphological variation in the male genitalia, especially with regard to the shape of the uncus, has been briefly discussed by several authors (Liu \& Pai 1979; Karsholt 1995; Huemer, pers. comm.). Liu \& Pai (1979), placing gibbosella in Chelaria, illustrated two different types (pl. V, Figs 12, 13) of male genitalia, which show differences in the gnathos and uncus. As concluded below, we consider them to represent two different species.

In order to clarify this complex the authors dissected and examined the genitalia of more than 60 Psoricoptera specimens, originating from several European countries and from Russian Far East, Japan and Korea. We could confirm that differences in the shape of the uncus (particulary) and in the number of spines on the aedeagus support the recognition of two widespread Palaearctic species, gibbosella and speciosella. The material from Asia studied by us moreover included two additional new species, which are described below.

In the descriptions of the genitalia below only characters of diagnostic significance are mentioned. In chapters on 'Other material examined' locality and dates are followed by a bracket containing information (when available) on collector, genitalia slides, and collection, separated by semicolons.
Abbreviations:

BMNH: The Natural History Museum, London, England.

CIS: The Center for Insect Systematics, Kangweon National University, Korea.

IBPV: Institute of Biology and Pedology, Vladivostok, Russia.

MGAB: Muzeul de Istorie Naturala "Grigore Antipa", Bucharest, Rumania.

OPU: Entomological Laboratory, Osaka Prefecture University, Sakai Japan.

RNHL: National Museum of Natural History, Leiden, The Netherlands.

TLMF: Tiroler Landesmuseum Ferdinandeum, Innsbruck, Austria.

TMB: Természettudományi Múzeum Állattára, Budapest, Hungary.

ZIAP: Zoological Institut, Academy of Sciences, St. Petersburg, Russia.

ZMHB: Zoologisches Museum, Humboldt Universität, Berlin, Germany.

ZMUC: Zoological Museum, University of Copenhagen, Denmark.

ZMUH: Zoological Museum, University of Helsinki, Finland.

\section{Species}

Psoricoptera Stainton

Psoricoptera Stainton, 1854: 100.

Phoricoptera Stainton, 1854: 76 (incorrect original spelling) (Sattler 1973).

Type species: Gelechia (Chelaria) gibbosella Zeller, 1839.

Diagnosis. Segment 2 of labial palpus with expanded ridge of loose scale-tufts beneath, slightly furrowed on ventral surface; segment 3 laterally flattened, thickened with loose scales dorsally. Forewing with well developed erect scale-tufts on upper surface; all veins present (Fig. 1), R3 arising from near upper corner of cell, R4 and R5 stalked near or beyond middle, R5 to costa, M1 separate from R4+5, M2 almost parallel with M1, $\mathrm{M} 3$ and $\mathrm{CuA} 1$ separated; $\mathrm{CuA} 2$ arising from near corner of cell; cell closed; hindwing with costa expanded anteriorly before middle ; Rs and M1 


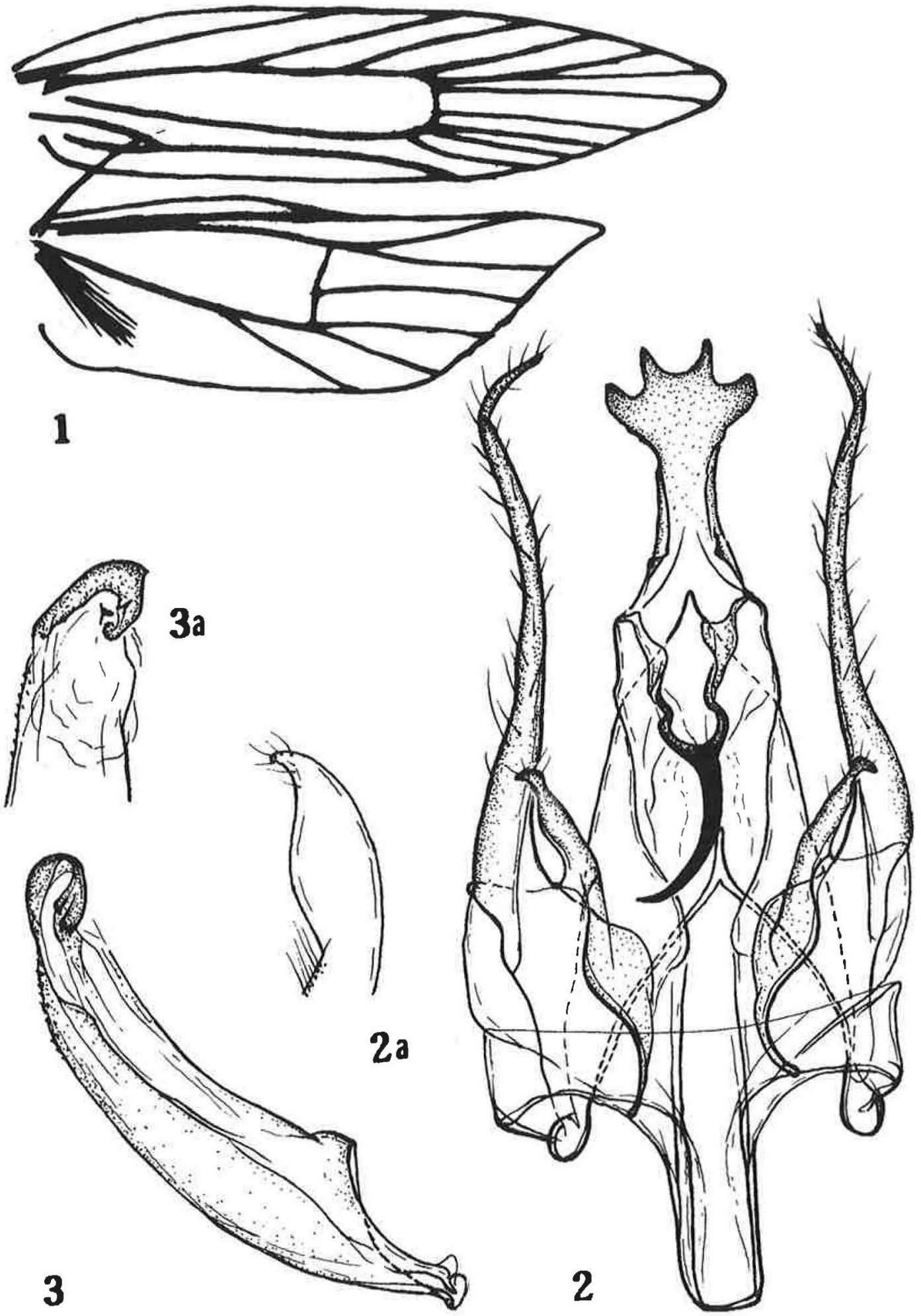

Figs. 1-3. Psoricoptera gibbosella (Zeller): 1. Venation; 2. Male genitalia; 2a. Lateral aspect of valvella; 3. Aedeagus; 3a. Lateral aspect of distal part of aedeagus. 


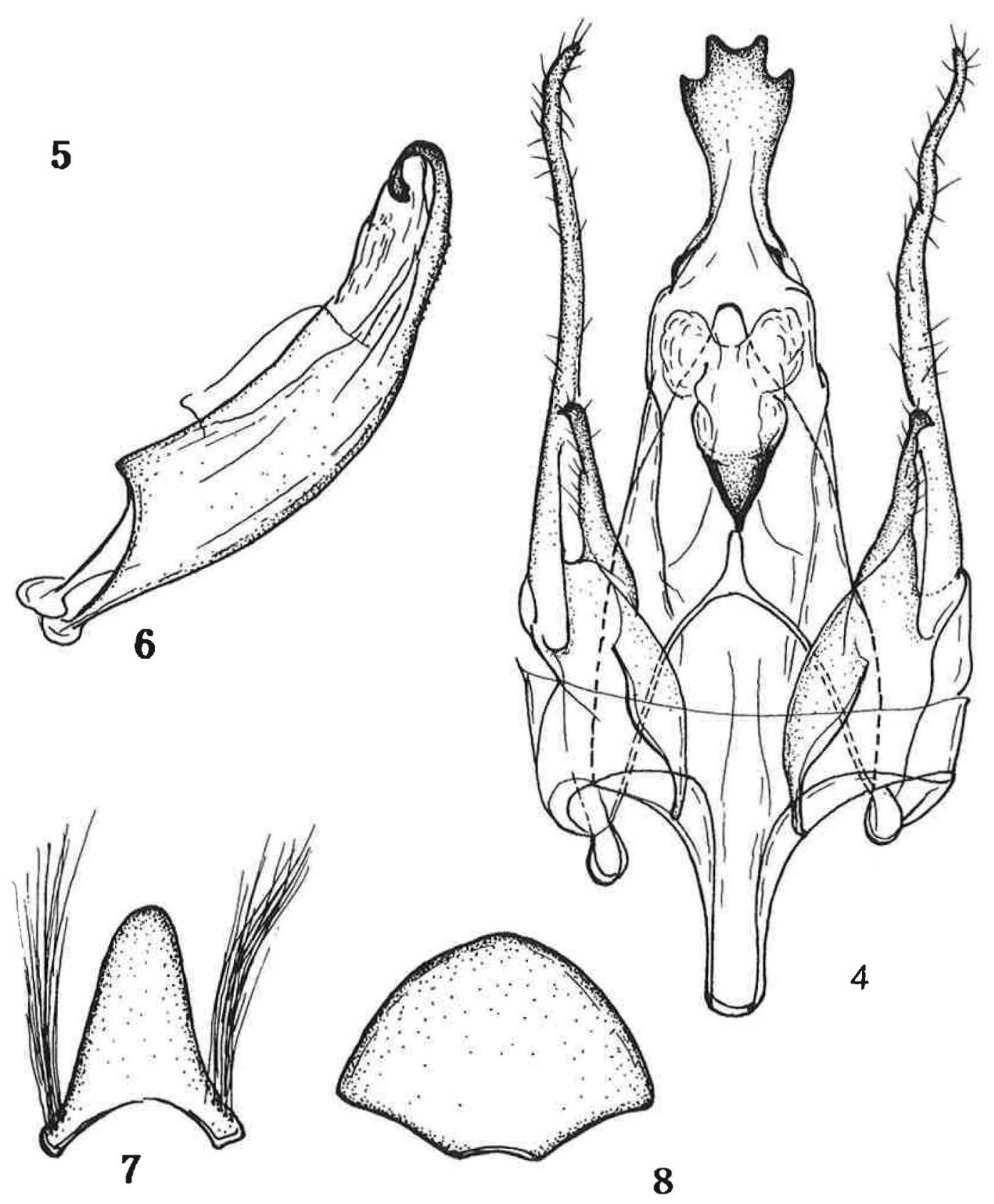

Figs. 4-8. Psoricoptera latignathosa sp. nov.: 4. Male genitalia; 5. Uncus; 6. Aedeagus; 7. Eighth tergite; 8. Eighth sternite. 
separated from upper corner of cell, M3 and CuA1 connate. Segment VIII in male with sclerotized plates (figs 7-8): membranous plate surrounding basal part of genitalia, with numerous semiovate scales laterally; Tergite VIII conical with a pair of long hair-pencils at lateral base; sternite VIII broad, fan-shaped, distal margin round, anterior margin slightly incurved.

Psoricoptera gibbosella (Zeller) (Figs. 1-3, 9-11, 16-23, 24-29, 34-38, 45-48)

Gelechia (Chelaria) gibbosella Zeller, 1839: 202 [examined].

Psoricoptera gibbosella: Stainton, 1854: 101.

Chelaria triorthias Meyrick, 1935: 589 [examined], syn. nov.

Psoricoptera triorthias (Meyrick, 1935): Ueda et al. 1995: 148.

Lita lepigreella Lucas, 1946: 98, syn. nov.

Adult (Figs 9, 47-48). Wingspan 14-20 mm. Labial palp covered with fuscous-brown, lightbased scales, segment 2 creamish at inner and upper surfaces, segment 3 laterally flattened with long, loose light-brownish scales. Head creme to light brown, laterally darker, with lighter face; thorax brownish; tegula with light brown to creme scales. Forewing brownish, mixed with whitish, blackish and occasionally orange scales; three erect scale-tufts at $1 / 4,2 / 4$ and $3 / 4$; an indistinct, angulated, whitish, subapical, transverse band; fringes dark at basal half, lighter towards tip. Hindwing greyish, darker towards apex, with light grey fringes.

Variation. In some specimens the whitish scales in forewing are particular prominent and can form an irrigular white, subcostal line. In other specimens there are nearly no white scales, and such specimens have a blackish-brown appearence. Occasionally such specimens have black, longitudinal lines (Fig. 9). Specimens which are nearly entirely whitish or blackish are rare. In most West Palacarctic specimens a considerable amount of red-brownish scales are present, whereas East Palaearctic specimens are more blackish.

Male genitalia (Fig. 2). Uncus variable (Figs 16-23, 45), but incisions of distal margin normally not strongly pronounced, and the median inci- sion is not normally deeper than well below the two lateral incisions; aedeagus (Figs 3,46) with more than 20 small spines on ventral surface beyond two-thirds.

Female genitalia (Fig. 24). Ostium plate (Figs. 24-29) subtriangular, shorter than wide, not tending backwards beyond base of apophyses anteriores; signum (34-38) hexagonal in outline, with diagonal groove, length about equal to width.

Remarks. A male from Austria inf., Ernstbrunn has a deeply emarginated median incision in uncus (Fig. 23) and 22 microspines on aedeagus, but the male genitalia are distinctly smaller than in most speciosella, and the forewings are with many reddish brown scales. It is here tentatively placed under gibbosella. Also in some specimens from Germany the median emargination of uncus is deeper than is usual for gibbosella (Fig. 45-46), but in other characters they agree with that species, and we consider them to represent individual variation.

A large (20 mm) male from Far East Russia, Askold Island has nearly uniform light brownish forewings (which may have been exposed to light). Its genitalia fit gibbosella well, apart from being of the size of speciosella. It is here assigned to gibbosella.

Gelechia (Chelaria) gibbosella Zeller was described from one male and four females caught around spruce in Berlin (Germany) in July. In the $\mathrm{BMNH}$ a female is already labelled as a lectotype by K. Sattler. It is published here for the first time (for data, see below).

Chelaria triorthias Meyrick was described from one male collected in July at Tokyo (Japan) by S. Issiki. We have examined the holotype in the BMNH. It is in a good condition, but the head is missing. The moth and its genitalia are figured by Clarke (1969: pl. 216). Specimens from Japan are generally more blackish and contrasting compared with European ones and may deserve subspecific status. However, having examined very little material from Japan, we refrain from deciding on this until sufficient material from other parts of Asia is available for comparison.

Lita lepigreella Lucas was described from an unspecified number of specimens from "Alger" (Algeria), collected by M. Lepigre on April 16, 1937. We have examined, in the BMNH, a colour 


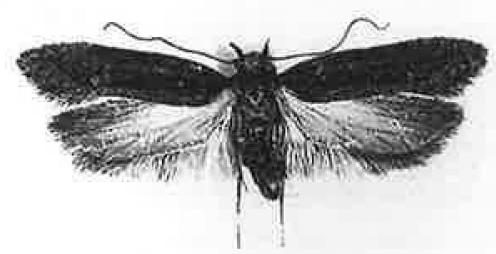

9
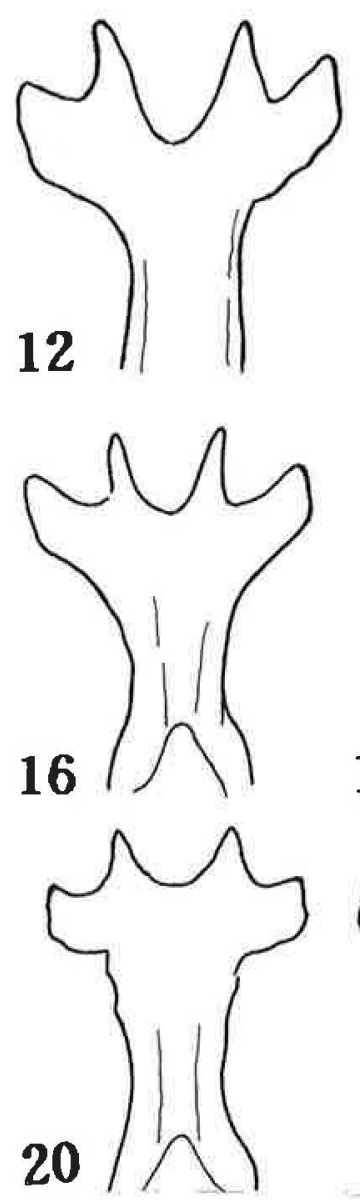

a
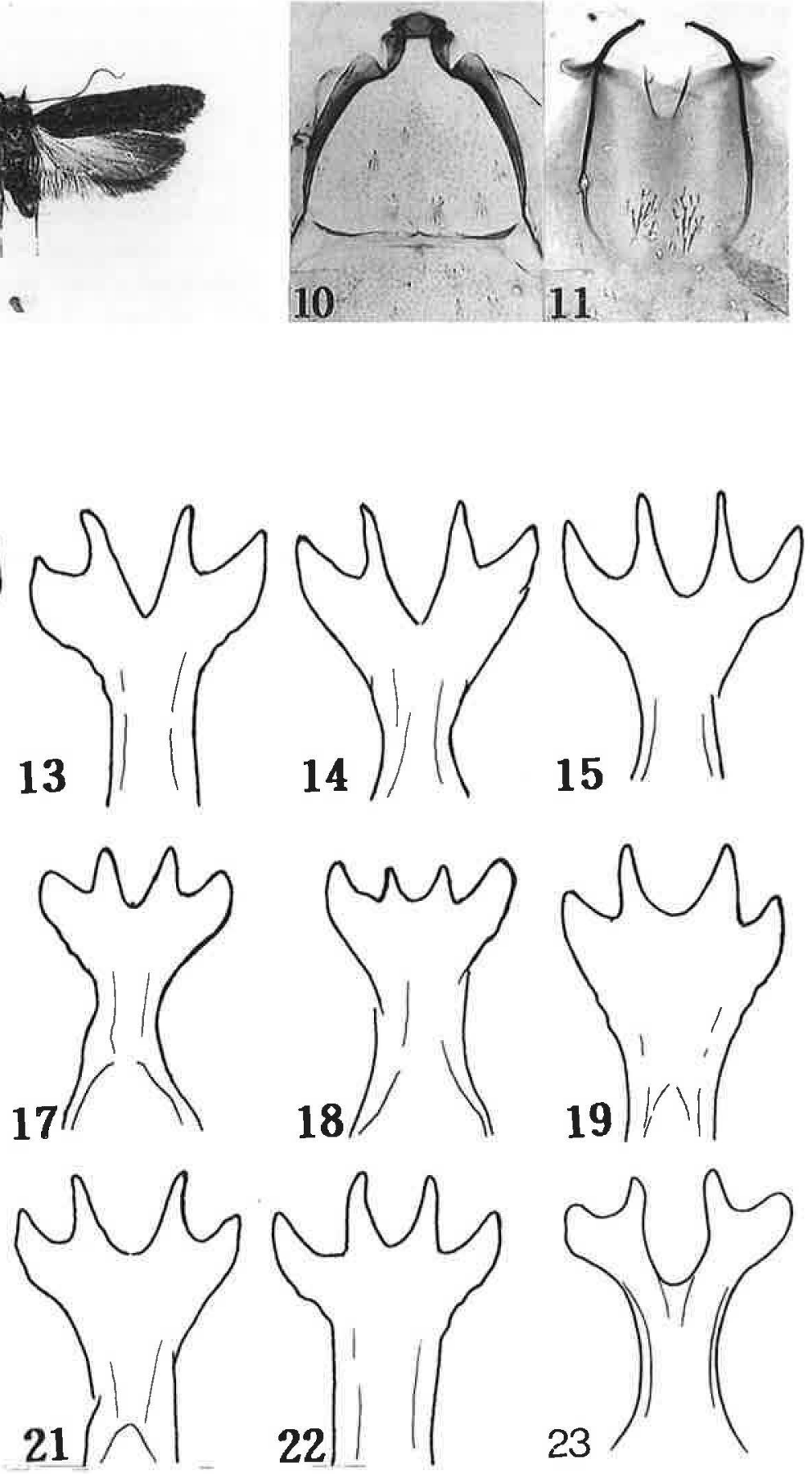

Figs. 9-11: Psoricoptera gibbosella (Zeller): 9. Adult of an unusual dark specimen from Germany; 10 . Tergite I-II; 11 . Sternite II; Figs. 12-23. Uncus of male genitalia of Psoricoptera: Figs. 12-15. P. speciosella Teich; Fig. 12. Finland (4144/Park); 13. Finland (4148/Park); 14. Finland (4146/Park); 15. Japan (1957/Park); Figs 16-23. P. gibbosella (Zeller): 16. Finland, (4154/Park); 17. Finland (4143/Park); 18. Finland (4145/Park); 19. Japan, Holotype of triorthias Meyrick (BM-8517); 20. Korea (1878/Park); 21. Korea (1785/Park); 22. European Russia (BM-26377); 23. Austria (OK 4651). 

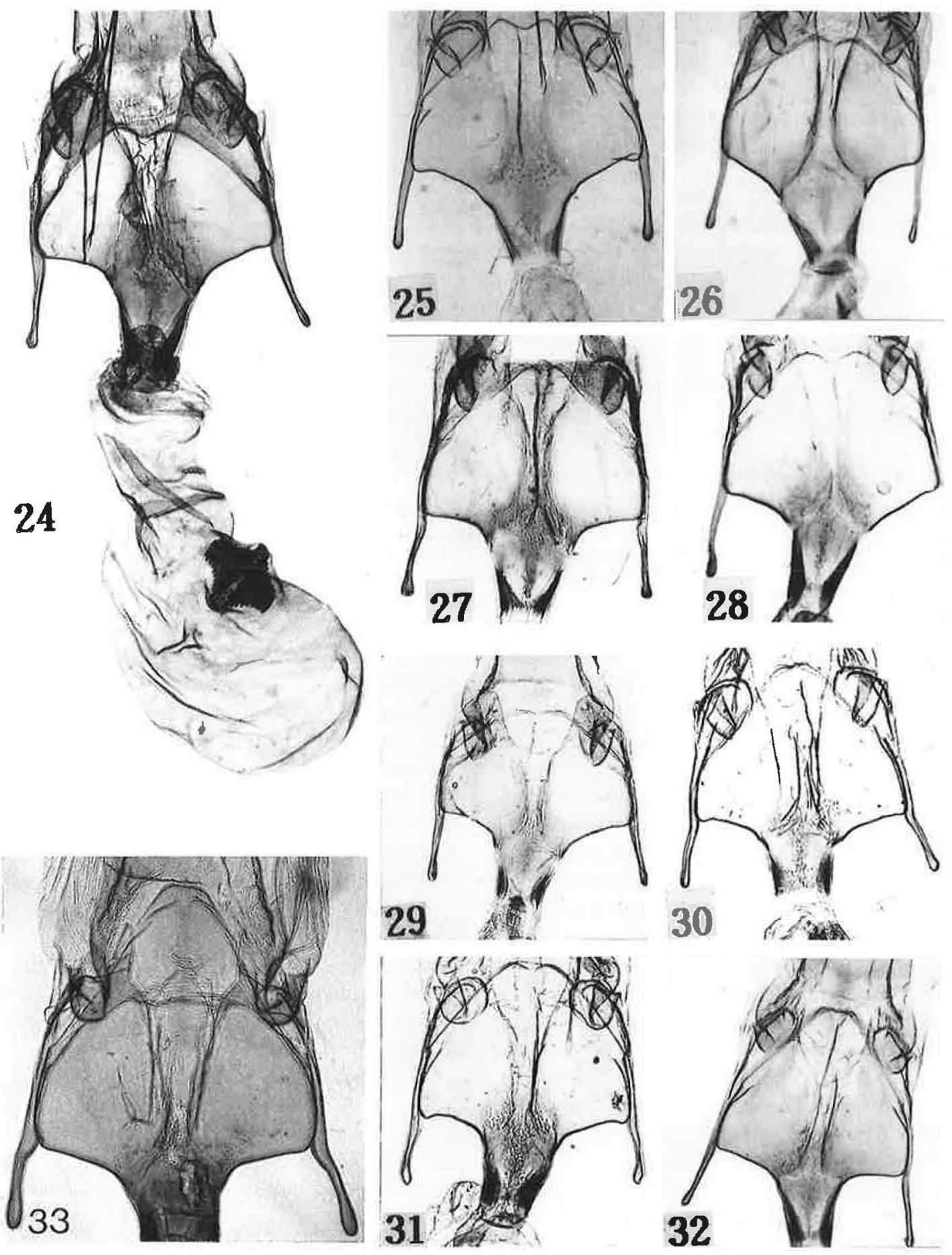

Fig. 24. Female genitalia of Psoricoptera gibbosella (Zeller), Korea (1837/Park): Figs. 25-33. Ostium plate of Psoricoptera; Figs. 25-29. P. gibbosella (Zeller): Fig. 25. Japan (1955/Park); 26. Japan (1880/Park); 27. Far East Russian (4153/Park); 28. Far East Russia (4152/Park); 29. Finland (4149/Park); Figs 30-32. P. speciosella (Teich): 30. Finland (4148/Park); 31. Finland (4150/Park); 32. Japan (1834/Park); Fig. 33. P. kawabei sp. n., (1839/Park). 

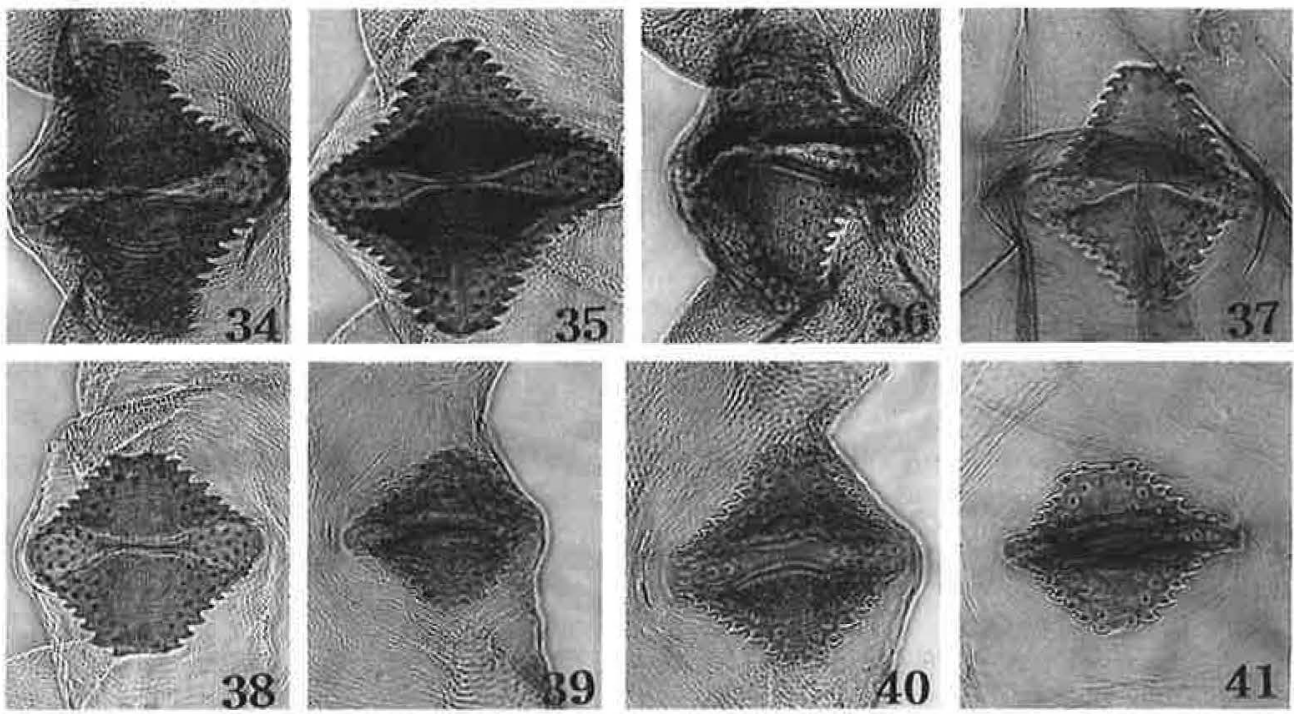

Figs. 34-41. Signa of Psoricoptera. Figs. 34-38. P. gibbosella (Zeller): 34. Korea (1837/Park); 35. Far East Russia (4147/Park); 36. Japan (1880/Park); 37. Finland (4149/Park); 38. Japan (1955/Park); Figs 39-41. P. speciosella Teich: 39. Finland (4148/Park); 40. Finland (4150/Park); 41. Finland (4151/Park).

slide of a female, labeled as type and belonging to the Museum National d'Histoire naturelle in Paris, and we are convinced that lepigreella is a synonym of gibbosella. Arahou et al. (1991) showed that gibbosella hibernates as an adult in North Africa.

Larva. The larva was first described by Stainton (1867) as: "Grey, with darker subdorsal line and slender, slightly darker dorsal line; head black; the second segment black, with the anterior edge whitish; anal segment with a small black plate; ordinary spots small and black". According to Kaitila (1996) it "is greenish grey with dark grey middorsal line. Abdorsal line absent". Most descriptions of the larva of gibbosella (e. g. by Meess 1910 ) originate from Lienig \& Zeller (1846), and refer to the larva of speciosella (see below).

Bionomics. The main host plant is Quercus sp., but it has occasionally been bred from Salix sp. (compare "Material examined" below). Records of larvae from Crataegus and Malus, as well as in galls of Eriophyes mites (Piskunov 1981) need confirmation. In Russian Far East it has been reared from Quercus mongolica, and Liu \& Pai (1979) gave, in addition to Quercus, also Juglans mandschurica and Salix sp. as host plants in China. However, it is apparent (see Liu \& Pai 1979, fig. 12) that these records probably included spec- imens of the following new species, $P$. latignathosa. Arahou et al. (1991) rapported gibbosella to be a pest in Morocco, where the larva lives in buds of Quercus ilex. They found that up to $45 \%$ of the buds could be destroyed. The adult flies from July and into the autumn. In N. Europe it is rarely seen later than medio September, but further south it is met with in late September and October, and from N. Africa it is reported to hibernate as an adult (Arahou et al. 1991).

Distribution. China, Japan, Korea, Russia (including Siberia and Far East), Europe, Asia Minor, N. Africa. Scarlato \& Gorodkov (1984) published a distribution map for gibbosella within former Sovjet Union, but their records certainly included speciosella as well.

Type material. 'Lectotype / 4/7 34, 33 / Zeller coll., Walsingham Collection, 1910-427/Lectotype + , Gelechia gibbosella Z., Select. K. Sattler, 1961 / B. M. + Genitalia slide No. 7143'. Paralectotype: labeled as lectotype, but numbered '32'.

'Type / Tokyo, Japan, 10.7.34 / $\sigma^{\star}$ genitalia on slide 4.XII.1948, J.F.G.C 8517 / Chelaria triorthias Meyr., 1/1, E. Meyrick det. in Meyrick Coll. / triorthias Meyr. / Meyrick Coll., B. M. 1938290 '

Other material examined. Armenia: $1{ }^{\star}, \mathrm{Ko}-$ 
sikoparan, 1901 (Korb; MGAB). Austria: 1 ㅇ, N. Tirol, Fritzens, la. 10.VI.1969 (Hernegger; P. Huemer/GEL 208; TLMF); 1 \%, N. Tirol, Ampass, 8.VIII.1969, (Hernecker; Huemer/GEL 211; TLMF); $10^{\star}$, inferior, Ernstbrunn, 21.VIII.1971 (M. \& W. Glaser; OK 4651; ZMUC); 1 우, superior, Linz, Schweiger, 4.IX.1987 (F. Lichten-berger; Huemer/GEL 208; TLMF). Czech Republic: 1 ㅇ, Bohemia, Praha, Krc, 11.X.1953 (V. Zouhar; ZMUC). Denmark: $10^{\circ}$, EJ, Stenholt, 29.VII.1974, (E.S. Nielsen; ESN 1180; ZMUC); $1 \sigma^{*}$, NEJ, Læs $\varnothing$, Skoven, 27.VII.1980 (O. Karsholt; OK 4659; ZMUC); 1 \% , LFM, Lolland, Blands Skifter, bred 12.VII.1920, in leaf of Salix caprea, (H.P.S. Sønderup; OK 4585; ZMUC); $1 \sigma^{\star}$, SZ, Basnæs, 3.VIII.1942 (P.K. Nielsen; OK 4584; ZMUC); 1 ㅇ, NEZ, Gadevang, 27.VII.1945 (N.L. Wolff; OK 4043; ZMUC); undissected specimens from Denmark: $33 \sigma^{\star}{ }^{\star}, 17$ 우 우 (ZMUC). Finland: $\mathrm{Ab}: 10^{\star}$, Turku, Ruissalo, 7.VIII.1921 (Clayhills; ZMUH); 1 ㅇ, ideb., 21.VII.1940, (Lankiala; 4154/Park; ZMUH); 3 o $^{\star}$, 1 o , ideb., 16-18.VIII.1979 (J. Jalava; 4143/Park, 4145/Park, 4149/Park; ZMUH); 2 ㅇ , Satava, 26.VIII.1936, 25.VIII. 1938, (W. Hackmann; P. Huemer 93/444, 93/445; ZMUH); Al: $2 \sigma^{\star} \sigma^{\star}$, Föglö, Bänö, 3.-4. VIII.1973 (J. Jalava; ZMUH). Germany: $1 \sigma^{\star}$, Krs Bitterfeld, Lingenau, 8. VIII.1982 (R. Sutter; OK 4560; ZMUC); 1 ㅇ, Württemberg, Markgröningen, Rotenecker, 25. VIII.1976 (L. Süssner; Huemer/GEL 209; TLMF); $1 \sigma^{*}$, Sachsen-Anhalt, Krs Bitterfeld, Pouch, 4. VIII.1996 (R. Sutter; Sutter 5219; Sutter). Greece: $1 \sigma^{*}$, Fthiotis, Ag. Konsta-tinos, Livantae, 2 m, 28.IX.1984 (M. Fibiger; OK 4657; ZMUC); $1 \sigma^{*}, 20 \mathrm{~km}$ NW Xanthi, Kallithea, 6.VII.1985 (B. Skule \& P. Skou; ZMUC); $10^{\star}$, Florina, 6 km W Psarades, 6.-8.IX.1991 (F. Schepler; ZMUC). Hungary: 1 đ', Budapest, Kamarae, 12.VII.19? (Uhrik; 6679/Gozmany; TMB) 1 \%, Apaj, 2.VII.1909 (Schmidt; 6678/Gozmany; TMB). Italy: 1 ㅇ, S. Tirol, Schnalstel, $800 \mathrm{~m}$, primo ix.1973, (F. Zürnbauer; Huemer/GEL 206; TLMF); 10 , Verona, Monte Baldo, San Zeno, 400 m, 1.-2.X.1983 (B. Skule \& P. Skou; OK 4647; ZMUC); $10^{\star}, 2$ 우, 일en, Auer, $200 \mathrm{~m}$, 29.VII.1990 (P. Huemer \& O. Karsholt; OK 4582, 4586; ZMUC). Japan: $20^{\star} \sigma^{*}, 1$ 우 [no further locality] (Pryer; BM 15778; BMNH); $10^{\star}$, Tama
Hill, Tokyo, 14.VII.1958 (A. Kawabe; CIS); $1 \sigma^{\star}$, 1 ㅇ, Nagano Pref., Setagaya, 13.VI.1965 (A. Kawabe; 1838/Park, 1880/Park; CIS); 1 으, Kiyosato, 1300m, Yamanashi-ken, 20. VIII.1972 (H. Inoue; CIS); 1 \%, Mt. Minaka, 23. VIII.1974 (A. Kawabe; CIS). 1 , Nakaizamurai, Tenyushimoina, 16.IX.1987 (M. Hara; CIS); $10^{*}, 2$ 은, Shirahone-guti, Azumi, Nagano, 1460m, 11. VIII.1988 (K. Fujisawa, 1954/Park, 1955/Park; CIS); 10 , Obikawa Anan, 430 m, Shimoina, Nagano, 16.X.1988 (K. Fujisawa; 1955/Park; CIS); 1 우 Kyushu, Kagoshima Pref., Amamioshima Is., Nishinakama, 1a. 6.iv.1996, host unknown (T. Ueda; TU 419; OPU); Korea: Gangweon Prov.: Chuncheon, $1 \sigma^{\star}$, 25.VII.1988, $3 \sigma^{\star}$, 19, 7.ix.1988 (K.T. Park; 1785/Park, 1878/Park; CIS); 1 \% , Mt. Keunbong-San, 5.VII.1985 (K.T. Park; 1384/Park; CIS); 1 우, Jeombong-san, 10. VIII.1992 (K.T. Park; CIS). Netherlands: $10^{*}$, Breda, 24.VIII. 1884, (Snellen; 1958/Park; RNHL); 1 ㅇ, Senep, 9. VIII.1877 (Snellen; 1959/Park; RHNL). Poland: $10^{\star}$, Ohalia [=Olawa] near Lissa, 17.VII.1865 (ZMHB); $10^{\star}$, Oswitz [=Auschwitz], 21.VII.1861 (ZMHB); 1 ๙ $^{*}, 1$ \% , Stettin [=Sczecin], 6.VII.1894 (ZMHB); 1 ㅇ, Torunia, Las Piwnicki, 31.VII.1978 (J. Buszko; ZMUC). Rumania: 10, Dobrogea, Hagieni, 8.-9.VII.1992 (L. Rakozy, ZMUC). Russia: $20^{\star} \sigma^{\star}, 2$ 우 9 , Kasakevitsch, 1908 (Korb; 4152/ Park, 4153/Park; MGAB); 1 đँ, 2 ㅇ 우, Gornotaezhnoe, $20 \mathrm{~km}$ SE Ussurysk, 23.-29.VI.1990, reared from Quercus mongolica; 1 ㅇ, ideb., 23.VI.1990 (M. Ponomarenko; IBPV), $10^{\star}$, Sarepta, [=Krasnoarmeysk], 12.VII.1885 (H. Christoph, BM 26377; BMNH); $1 \sigma^{\star}$, ideb., without date (MNHU); $1 \sigma^{\star}$, Vladivostok, Askold Isl., 1883 (Dör.; K. Sattler 503a; MNHU); $1 \sigma^{\prime}$, Amur Oblast., between River Perog and River Bol'schaja Ergelia, la. 19.VI.1959, Quercus mongolica (bred 14.VII.1958), (Kuznetsov \& Suhareva (ZIAP). Spain: 1 , Andalusia, Camino d. Rhonda, Urb. Madronal, Loma de Colmas, 500 m, 14.X.1988 (E. Traugott-Olsen; ZMUC). Tunisia: 1 , Ain Draham, 21.VII.1886 (Eaton; BMNH); Turkey: 1 ㅇ, Anatolien, Ak-Chehir, 1900 (Korb; MGAB); 1 đ', Prov. Mersin, Taurus, Gözeloluk NW Erdemli, 1400 m, 16.VII.1986 (M. Fibiger; OK 4649; ZMUC). 
Psoricoptera speciosella Teich (Figs. 12-15, 30-32, 39-41, 49-50)

Psoricoptera speciosella Teich, 1893: 358.

Adult (Figs. 49-50). Wingspan 17-21 mm. Very similar to gibbosella, but with forewing more blackish, or blackish and whitish, only occasionally with brownish areas.

Variation. In some specimens the whitish scales form an irrigular subcostal line, and rarely they cover most of the costal half of the forewing. Occasionally specimens with many red-brownish scales, especially in dorsal half, occur.

Male genitalia. Very similar to those of gibbosella, but slightly larger; median incision of distal margin of uncus between inner lobes strongly emarginated, reaching well beyond the incision of the two lateral incisions (Figs. 12-15); aedeagus with less than 16 microspines on ventral surface beyond two-thirds.

Female genitalia. Ostium plate (Figs. 30-32) posteriorly more acute and less distinctly intended medially than in gibbosella, its length and width almost equal, extending backwards beyond base of apophyses anteriores; signum (39-41) generally smaller than that of gibbosella, variable, but usually shorter than wide, whereas in gibbosella the length and width are subequal. Apophyses anteriores usually longer than in gibbosella.

Larva. The larva was first described by Lienig \& Zeller (1846) (under the name of gibbosella) (translated from German): "It is first light dust-grey with fine black warts with a few light hairs. Later it becomes light brown-whitish with a dark grey line on each side of the abdomen; head blackish, prothoracic plate and thoracic legs black; anal plate bone white. At last it changes again into pale apple-green. The warts, which look as black dots, have a light brownish hair; along the back runs a fine grey-green line with small, rounded, rosa-reddish spots in the incisions between the segments. Along the sides of the abdomen is a brownish line, and above the abdominal legs a line composed of rosa reddish spots. Head dark brown; prothoracic plate wax-yellow, posteriorly and laterally blackish edged; thoracic legs black". Recently the larva has been described as "pale brownish grey with reddish brown middorsal line. Abdorsal line reddish" (Kaitila 1996).
Bionomics. The larva is slim and quick and bends an edge of a leaf of the hostplant close around its body (Lienig \& Zeller 1846). It feeds on leaves of Salix sp. in late June and early July (Kaitila 1996). A larva found on "Wollweide" [Salix cf. caprea] in the beginning of June pupated at the 25th of June and the adult emerged at the 20th of July (Lienig \& Zeller 1846). The adult moth flies from late July to late September. In Finland and Sweden it is a little later on the wing than gibbosella (Kaitila 1996, Svensson 1982). Aarvik (1987) reported upon finding of a larvae of speciosella already the 26th of May.

Distribution: Finland, Germany, Japan, Norway, Poland, Russia, Sweden. Recently reported from France (Nel \& Varenne 1996).

Remarks. According to Kaitila (1996) the genitalia of speciosella are larger than those of gibbosella. Our measurements show them to be about 10-15\% larger (at least in N. European specimens), but speciosella is, on average, larger than gibbosel$l a$, wherefore the relative size of the genitalia may be the same in both species.

In one specimen from Japan the gnathos are shorter and broader, resembling that of $P$. latignathosa $\mathrm{n}$. sp. However, it has the uncus similar to speciosella, and it was bred from Salix together with a female, which has the genitalia similar to those of speciosella (Fig. 32). It is here tentatively listed under that species, but we are aware that it may well represent a further, undescribed species.

Kaitila (1996) stated the larva of gibbosella and speciosella to differ in colour. However, also in these character there seems to be some variation, when one compare his descriptions with those given by Stainton (1867) and Lienig \& Zeller (1846) (see above). Further research is needed to prove if constant morphological characters exist between the larva of gibbosella and speciosella.

The host plant association of the larva of gibbosella with Quercus spp. and speciosella to Salix spp. is apparently an important diagnostic character for these two species in both Europe and Asia. Even though we examined a specimen of gibbosella which was, according to its label, bred from Salix, cases of host plant shifts between these two species are at most very occasional. There 
may, moreover, be some doubt about the correctnes of this information as it is known that the collector, H. P. S. Sønderup, in some cases labeled bred specimens according to the host plant(s) given in the literature, when he could not remember from where he bred the moths (O. Karsholt, unpubl.). At his time most literature records of host plants for gibbosella were based upon Lienig \& Zeller's (1846) record from Salix, which originated from a misidentified larva of speciosella. New, well documented records of larvae of gibbosella from Salix or speciosella from Quercus would therefore be important.

Psoricoptera speciosella Teich was described from a single specimen collected at Dudeln in Latvia. The collection of Teich is considered lost, but the identity of speciosella has been generally accepted.

Material examined. Finland: $\mathrm{Ka}: 30^{\pi} \sigma^{\top}, 2$ 우 우, Virolahti, 2.-18.VIII.1975 (J. Jalava; 4142/Park, 4148/Park, 4150/Park; ZMUH); 1 ơ $^{\star}$, ideb., 16.28.VIII.1979 (E. Laasonen, ZMUC); Ab: 1G Loja, 1.VIII.1975, 1 o 18.VIII.1978 (H. Krogerus; OK 4652; ZMUC); $10^{\star}$, Karisloja, 18.VIII.1978 (H. Krogerus; ZMUC); $N$ : 2 우, Porvoon mlk., 15.VIII.1970, 2.IX.1972 (E. Suomalainen; OK 4044; ZMUC); 1 우, ideb., 5.-7.VIII.1980 (L. Löfgren; ZMUC); $1 \sigma^{\star}$, Nurmijärvi, 18.VIII.1971 (J. Jalava; ZMUH); $10^{*}, 1$ 운 Helsingfors, 23.VIII.1975 (Nybom; 4151/Park; ZMUC, ZMUH); $3 \sigma^{\star}, 2$ 우, Helsinki, Kannelmäki, 31.VII.-2.VIII.1979 (J. Jalava; P. Huemer 93/443, 93/444, 4146/Park; ZMUH); $1 \sigma^{\star}$, Espoo, 11.14.IX.1982 (L. Löfgren; ZMUC). Germany: $10^{\star}$, Leutstetten, $590 \mathrm{~m}$, primo IX.1966, $1 \sigma^{\star}$, ultimo VIII.1968 (F. Zürnbauer; Huemer/GEL207, 210; TLMF); 10 , Blankenburg, Schwarzatal, 11.VIII. 1988 (H. Steuer; HS 3383; Steuer). Japan: Nagano Pref: $1 \sigma^{\star}, 1$ 우, Setagaya, 5.-10.VII.1964, bred from Salix sp. (A. Kawabe; 1834/Park, 1835/Park; CIS); $1 \sigma^{*}$, Kisojihara, Nagawa, 25.VIII.1984 (K. Fujisawa; 1957/Park; CIS); $10^{\star}, 1$ ㅇ, Hokkaido, Tokachi, Shikaoi, Shikaribetsukyo, 24.VIII.1981 (J. Kanazawa; OK 4650, OK 4654; ZMUC). Poland: $1 \mathrm{o}^{\star}$, Puszcza Bialowieska, Park Narod, 25.VIII.1965, 1 \% , 26.VIII.1966 (S. Adamczewski; OK 4653, OK 4658; ZMUC). Russia: $30^{\star}, 1$ 우, Altai, Teletshoe oz., Artybas biol. st., 18.-22.VIII.
1982 (K. Mikkola; ZMUC, ZMUH); 1 o $^{\star}$, SU, Bez. Perm, Verdichter station Ordinskaja, 28 km Ösö Barda, 300-400 m, 8.-9.VIII.1987 (T. Karish; $\mathrm{BMNH}) ; 8 \sigma^{\star}, 5$ ㅇ, Far East, Primorskij Kraj, Shkotovo distr., Anisimarka, 19.VII.-7.VIII.1994 (N. Savenkov, ZMUC).

Psoricoptera latignathosa sp. n. (Figs. 4-8, 51)

Diagnosis. In external characters very similar to gibbosella (Zeller) and speciocella Teich, apart from that the forewing (of the somewhat worn holotype) has no whitish or brownish scales, the postmedian line of forewing is followed by black scales, and the fringes of hindwing has a dark fringe-line. For differences from $P$. kawabei q. v. In the male genitalia latignathosa is unique in having the gnathos extremely broad towards base (not narrowed and sickle-shaped as in the two above mentioned species), and uncus with only slight incisions in distal margin.

Adult (Fig. 51). Wingspan $18 \mathrm{~mm}$. Head and thorax greyish brown. Antenna and labial palp typical for the genus. Forewing greyish with scattered black markings; three prominent, erect, blackish scale-tufts: two larger, longitudinal ones are located posteriorly to cell, one at distal end of cell, and a couple of smaller ones are irregularly scattered over the wing; an indistinct, angulated, light grey, subapical, transverse band is followed by black scales; fringes dark at basal half, distally lighter. Hindwing greyish, darker towards apex; fringes greyish, with darker, basal fringe-line.

Male genitalia (Fig. 4). Gnathos broad basally, triangular, with pointed apex. Uncus (Fig. 5) only slightly emarginated or incised on distal margin, with lateral lobes very short (this character may prove to be variable); saccus narrower than in related species; aedeagus (Fig. 6) with less than 15 inconspicuous microspines beyond twothirds.

Female. Unknown.

Bionomics. Immatures and host plant unknown (but see "Remarks" below). The holotype was collected in late July.

Distribution. China, Korea.

Remarks. The male genitalia figured by Liu \& Pai (1979: Fig. 12) under the name of gibbosella 

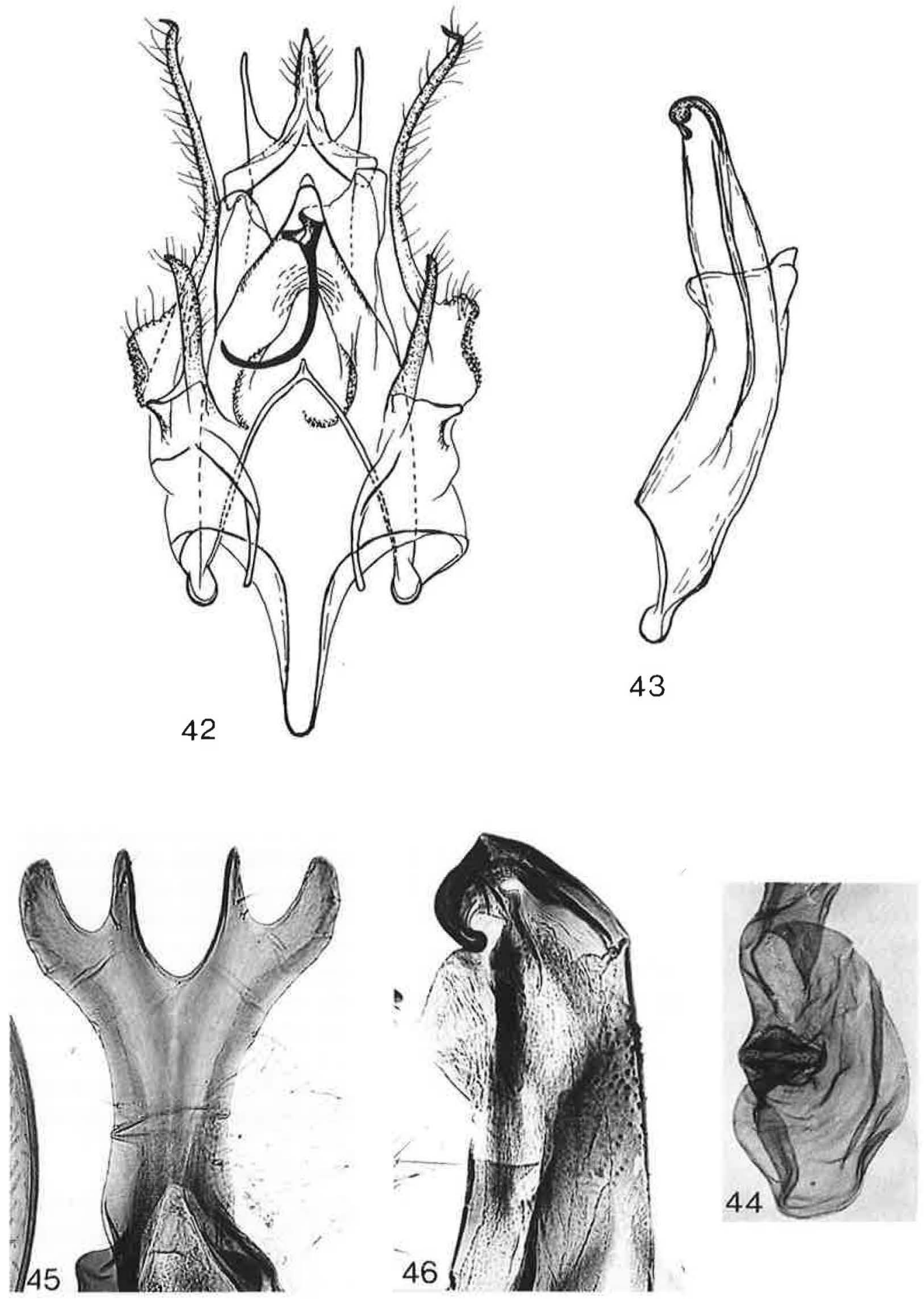

Figs. 42-44. Psoricoptera kawabei sp. n. Fig. 42. Male genitalia (1956/Park); Fig. 43. Aedeagus (1956/Park); Fig. 44. Corpus bursa with signum (1839/Park); Figs. 45-46. Psoricoptera gibbosella (Zeller), Austria (Sutter 5219); Fig. 45. Uncus; Fig. 46. Lateral aspect of distal part of aedeagus. 

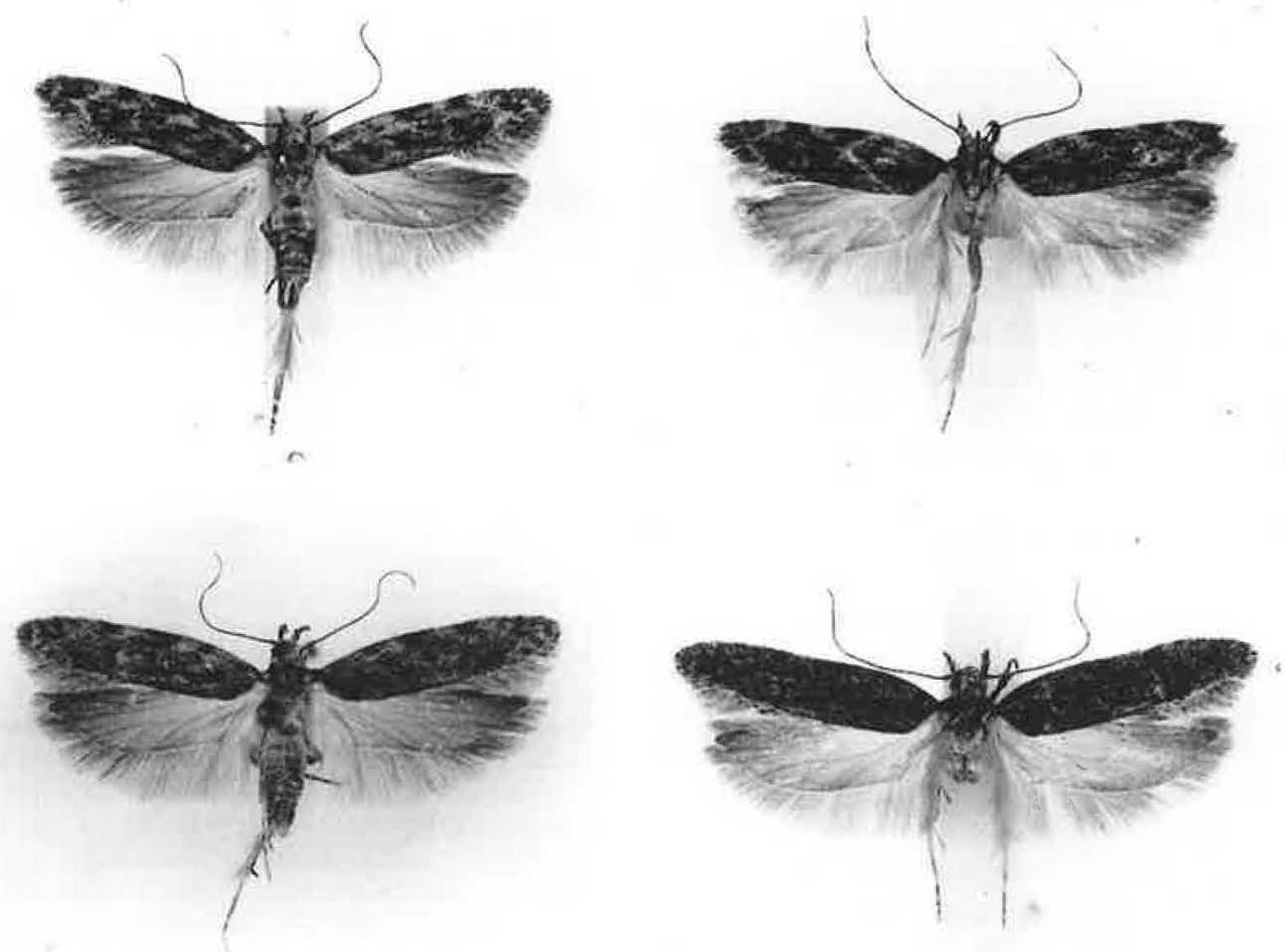

49
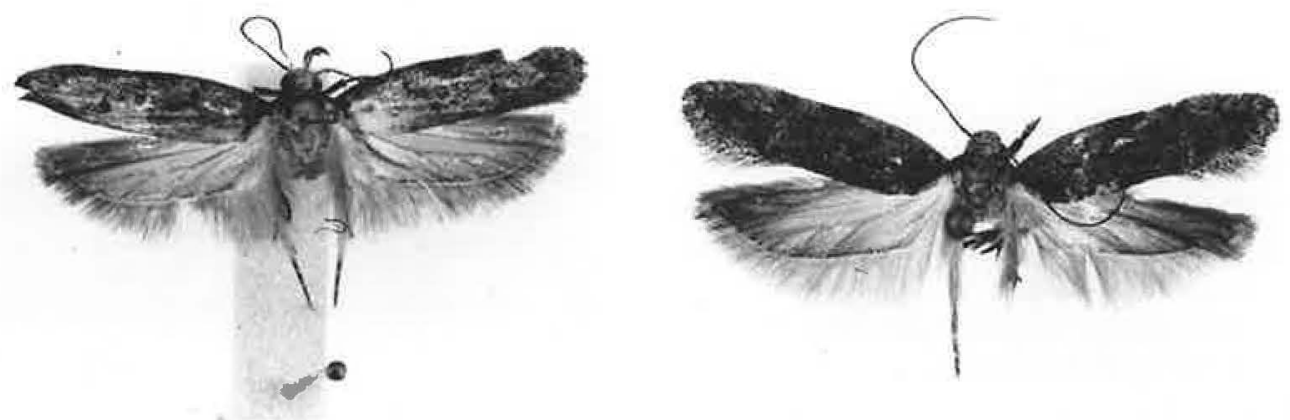

Figs 47-52. Adults of Psoricoptera (x 3). Figs 47-48. P. gibbosella (Zeller) Fig. 47. c, Denmark. Fig. 48. $\sigma^{\star}$, Korea; Figs. 49.-50. P. speciosella Teich: Fig. 49. ${ }^{*}$, Finland; Fig. 50. $\sigma^{*}$, Japan; Fig. 51. P. latignathosa sp. n., Holotype $\delta^{*}$, Korea; Fig. 52. P. kawabei sp. n., E, Japan.

obviously belong to latignathosa. In the description (in Chinese) of the adult, larva, and biology of their gibbosella, they listed as host plants Quercus sp., Juglans mandschurica and Salix sp., and it is possible that the host plant of latignathosa is one of these trees. We have had no opportunity to examine the material studied by Liu \& Pai.

Type material. Holotype: $\sigma^{*}$, Korea, Gangweon Prov., 10 km N Chuncheon, Chugog, 30.VII.1986 (K.T. Park; 1786/Park; CIS). 
Psoricoptera kawabei sp. n. (Figs. 33, 42-44, 52)

Diagnosis. In external characters similar to the three other Psoricoptera species, apart from being slightly larger. From most specimens of gibbosella and speciosella it can be separated by having no brownish or whitish scales, and from latignathosa by its dark hindwings without darker fringe-line. In the male genitalia kawabei is characterized by the shape of the uncus, the well developed distal lobes of tegumen, the slender gnathos, and the narrow saccus. In female genitalia the different shape of the ostium plate is characteristic.

Adult (Fig. 52). Wingspan 19-20.5 mm. Labial palp brownish, mixed with blackish-brown scales. Head light brown; thorax dark brown; tegula with light brownish tip. Antenna dark brown, indistinctly lighter ringed. Forewing with three prominent, erect scale-tufts, fuscous-brown with indistinct blackish markings, most prominent at basal part of dorsum, in middle of costa and near apex; fringes dark at basal half, lighter distally. Hindwing light fuscous, darker towards apex; fringes dark grey, without fringe-line.

Male genitalia (Fig. 42). Tegumen with symmetrical, slender distal lobes, arising from near base of uncus; uncus narrow, laterally with setae, apex pointed, turned down ventrally; gnathos sickle-shaped, very slender, with small base; valva slender, exceeding apex of uncus; aedeagus (Fig. 43) relatively slender, without microspines on ventral surface.

Female genitalia. Ostium plate (Fig. 33) larger compared with that of previous species, divided into two parts; apex clearly extending beyond base of apophyses anteriores and only slightly emarginated; signum (Fig. 44) short, about two thirds of width, elongated horizontally.

Host. Rhus chinensis Mill. (Anacardiaceae).

Distribution. Japan.

Remarks. We consider it likely that the male holotype and the female specimens are conspecific, as they are similar in external appearance, have a large wingspan, very characteristic genitalia compared to the other Psoricoptera species, and they were collected in the same area. However, as we have no definite proof for this we ex- clude the females from the type series.

Etymology. This new species is named after the late Mr. A. Kawabe who collected and reared larvae of this species.

Type material. Holotype: G, Japan, Nagano Pref., Shimonia, Tamoto Yasuoka, 23.VIII.1982 (M. Hara; 1956/Park; CIS).

Material excluded from type series. Japan: 1 우 Gunma Pref., Tanigawa, 6.VII.1973, bred from Rhus chinensis (A. Kawabe; 1839/Park; CIS). 1 우, Gunma Pref., Minakami, 23.VIII.1974 (A. Kawabe; 1882/Park; CIS).

Acknowledgements. We would like to express our thanks to Dr. P. Huemer, TLMF, Innsbruck, Austria for placing at our disposal specimens and genitalia slides prepared for his own research. We also acknowledge the help received from Dr. L. Gozmány, TMB, Budapest, Hungary; Mr. J. Jalava and Dr. L. Kaila, ZMUH, Helsinki, Finland; Dr. H. Krogerus, Helsinki, Finland; Dr. A.L. Lvovsky, ZIAP, St. Petersburg, Russia; Dr. W. Mey, ZMHB, Berlin, Germany; Dr. E. van Nieukerken, RNHL, Leiden, The Netherlands; Dr. M.G. Ponomarenko, IBPV, Vladivostok, Russia; the late Dr. A. Popescu-Gorj, MGAB, Bucharest, Romania; Dr. K. Sattler, BMNH, London, Great Britain, and Mr. T. Ueda, OPU, Osaka, Japan, who provided information and loaned us material under their care. Mr. A. Fujisawa, and the late Mr. A. Kawabe, both of Tokyo, Japan provided valuable specimens for KTP, and Mr. M. Fibiger, Sor $\phi$; Mr. F. Schepler, Vejle; Mr. P. Skou, Stenstrup, Mr. B. Skule, Rødovre, all of Denmark, Dr. N. Savenkov, Latvijas Dabas muzejs, Riga, Latvia, and Mr. E. Traugott-Olsen, Marbella, Spain presented material of Psoricoptera to ZMUC. Prof. N. P. Kristensen and Dr. Leif Lyneborg, ZMUC kindly commented upon the manuscript, and Mr. P. Stadel Nielsen, Holte, Denmark gave technical advice.

Most figures were prepared by KTP, but fig. 23 was drawn by Ms. B. Rubæk, ZMUC, and fig. 45-46 was provided by Mr. R. Sutter, Bitterfeld, Germany. The photographs used for fig. 9 and 47-52 were taken by Mr. G. Brovad, ZMUC.

\section{References}

Aarvik, L. 1987: Contribution to the knowledge of the Norwegian Lepidoptera II. - Fauna norv., Ser. B, 34: 7-13.

Arahou, M., Aguesse, P. \& Bigot, L. 1991: Premières données écologiques et biologiques sur Psoricoptera gibbosella (Zeller), nouveau ravageur du chêne vert au Maroc (Lepidoptera: Gelechiidae). - Anns Soc. ent. Fr. (N.S.) 27: 65-68.

Clarke, J. F. G. 1969: Glyphipterigidae - Gelechiidae (A-C). Catalogue of the Type Specimens of Microlepidoptera in the British Museum (Natural History) described by Edward Meyrick 6: 1-537.

Kaitila, J.-P. 1996: Suomen jäytäjäkoiden (Gelechiidae) elin- 
tavat. - Baptria 21: 81-105. (In Finish with English summary)

Karsholt, O. 1995: Kommentiertes Verzeichnis der Symmocidae, Blastobasidae und Gelechiidae Ostdeutschlands (Lepidoptera). - Beitr. Ent. 45: 137-154.

Karsholt, O. \& Riedl, T. 1996: Gelechiidae (excl. Gnorimoschemini). — In: Karsholt, O. \& Razowski, J. (eds.): The Lepidoptera of Europe. Pp. 103-113, 118-122, 310-312. Stenstrup.

Lienig, F. \& Zeller, P. C. 1846: Lepidopterologisches Fauna von Lievland und Kurland. - Isis, Jena 39: 175-302.

Liu, Y. \& Pai, K. 1979: A study on the gelechiid moths in Tai-Ling Forest Areas of Heilungkiang Prov [in Chinese]. Scientia Silvae sinicae 15: 276-280, pl. IV-VI.

Lucas, D. 1946: Lépidoptères nouveaux pour l'Afrique du Nord. - Bull. Soc. ent. Fr. 51: 96-98.

Meess, A. 1910: XXXVIII. Fam. Gelechiidae. - In: Spuler, A.: Die Schmetterlinge Europas 2. Pp. 330-380, pls. 8789. Stuttgart.

Meyrick, E. 1925: Lepidoptera Heterocera, Fam. Gelechiadae. - In: Wytsmann, P. (ed.): Genera Insectorum 184:1290, pls 1-5.

Meyrick, E. 1935. Exotic Microlepidoptera 4(18-19):545-576. London.

Nel, J. \& Varenne, T. 1996: Psoricoptera speciosella Teich, 1892, espèce nouvelle pour la faune de France (Lep., Gelechiidae). - Bull. Soc. ent. Fr. 101:144.

Piskunov, V. I. 1981: Gelechiidae. - In: Medvedev, G. S. (ed.): Opredelitel' Nasekomykh Evropiskoi Chasti SSSR
IV, Cheshuekrylye 2: 649-748. [English translation, 1990: Keys to the Insects of the European Part of the USSR IV, Lepidoptera, part 2:889-1024].

Pitkin, L. M. 1984: Gelechiid Moths of the genus Mirificarma. - Bull. Br. Mus. nat. Hist. (Ent.) 48:1-70.

Sattler, K. 1973: A Catalogue of the Family-Group and Genus-group Names of the Gelechiidae, Holcopogonidae, Lecithoceridae and Symmocidae (Lepidoptera). Bull. Br .Mus. nat. Hist. (Ent.) 28:155-282.

Scarlato, O. A. \& Gorodkov, K. B. 1984: Areale der Insekten des europischen Teils der USSR. Atlas (Hft. 5). In: Gorodkov, K. B.: Range types of insects of tundra and forest zones of European part of USSR [in Russian]. - "Hauka" Akad. Wiss. USSR, pp. 3-20, maps 179-221, kep. maps 193-212.

Stainton, H. T. 1854: Insecta Britannica. Lepidoptera: Tineina. viii +313 pp., 10 pls. London.

Stainton, H. T., 1867: Observations on Tineina. - The Entomologist's Annual for 1867: 17-30.

Svensson, I. 1982: Anmärkningsvärda fynd av Microlepidoptera i Sverige 1981. - Ent. Tidskr. 103: 81-88.

Teich, C. A. 1893: Ueber einige in Livland gefundne Schmetterlinge. - Stett. ent. Ztg. 53(1892): 355-359.

Ueda, T., Yamate, Y. \& Sagara, I. 1995: Gelechiid fauna of Asa Town, Asakita-ku, Hiroshima City. - Trans. lepid. Soc. Japan 46: 145-152.

Zeller, P. C. 1839: Versuch einer naturgemässen Einteilung der Schaben. - Isis, Jena 1838: 167-220. 